\title{
4. 骨粗鬆症
}

\author{
中 村 利 孝*
}

\section{1. 疾患概念と骨量による診断基準}

骨粗硹症は低骨量と骨組織の構造異常のどちら か、または両方の要因により骨格が脆弱になり、 骨折の危険性が増加した状態と定義されている。 この定義は、骨粗箖症を「骨折リスクの上昇」と 定め、その要因に低骨量と構造脆弱化の 2 つを含 めた点が画期的であった。さらに、WHOでは骨 折発生頻度の検討から、骨量に2つの閔値を設定 し、若年成人の $-2.5 \mathrm{SD}$ 未満を骨粗柏症、 $-1 \mathrm{SD}$ と -2.5SDの間を骨量減少症とする診断基準を提示し た。アメリカ、ヨーロッパもこの基準を採用して いる。

\section{2. 骨構造脆弱化の取り扱い}

しかし、骨量だけでは、骨量減少が著明でなく ても骨構造の脆弱化により骨折する例を診断でき ない。実際、骨量減少症で非外傷性骨折を有する 例があり、そのような例では、新たな骨折発生率 も高い。そこで、WHOでは骨量は骨量減少症の範 囲であっても、非外傷性骨折がある例は、骨粗钐 症と診断することにした。

\section{3. 日本の診断基淮の特徵}

日本骨代謝学会の診断基準でも、低骨量と構造 脆弱化を主要項目とした点はWHOの基準と同じで ある。日本人の骨折有病率と骨量との関係から、

* 産業医科大学整形外科

干 807-8555 北九州市八幡西区医生ヶ丘 1-1
若年成人平均の-2.5SD と-1.0SDに相当する闌値 を、70\%と80\%という馴染みやすい表示にした。 また、腰椎X線像による構造異常の判定も取り入 れ、骨量測定をしなくても診断できるようにして いる。

\section{4. 大規模骨折介入試験の意義}

最近、骨粗鬆症の骨折について、骨吸収抑制剂 を用いた 2000 人以上を対象とし 3 年以上観察した 骨折介入試験の結果が公表された。その結果では、 骨粗槮症における骨量低下と骨の脆弱性とは、必 ずしも一致しないことが確認された。プラセボ群 の脊椎骨折発症頻度をみると、脊椎骨折のある例 では1年で約5.0-7.2\%であり、春椎骨折がなく骨 量がT值でー2.5未満で診断された例では、0.95 - $1.5 \%$ であった。すなわち、脆弱性骨折で診断さ れる例と低骨量のみで診断される例とでは、骨折 の危険性に5倍近く差がある。また、治療効果につ いては、骨粗豦症例では、2-7\%程度の骨量増加 で50\%近くも骨折発症率が抑制された。一方、骨 量がT值でー2.0以上の例では、骨量増加は得られ るが、骨折発症率は抑制されなかった。これらの 事実は、1。骨脆弱性は骨量低下とは別個に存在 すること、2，骨吸収抑制剤は、骨脆弱性を有す る例では、骨折リスクを実質的に減少させ、その 効果は、骨量の上昇効果に比べて遥かに大きいこ と、3、骨脆弱性のない例では、骨吸収抑制によ る骨折防止効果は発揮されにくいこと、を示して いる。 
海綿骨では骨量が同じであっても骨強度には2倍 程度の開きが生じることはある。マイクロCTの観 察では、骨梁にはロッド状のものとプレート状の ものが観察される。海綿骨構造の基本的なパター ンが、骨量とは別個に骨の脆弱性に関連する可能 性はある。また、骨吸収抑制剤は、骨表面の吸収 㸗数減少させるので、骨脆弱性が高まっている状 態では、このような作用が決定的な違いを生じる 可能性もある。いずれにせよ、骨吸収抑制剂の脊 椎骨折防止効果は、骨脆弱性の改善によるもので、 骨量増加による直接的な効果ではないのかも知れ ない。

5. 骨粗箖症の治療適応

骨折介入試験は、低骨量と脆弱性骨折の存在の $2 つ$ 着目点とした、二本立ての診断基準の妥当 性を、確認したことになる。最近、アメリカ骨粗 箖症財団では、閉経後女性で非外傷性脊椎骨折の ある例では、骨量測定をせずに治療を開始し、脊 椎骨折の無い例でのみ骨量を測定することを勧め ている。骨量の値にかかわらず非外傷性骨折の存 在は、それ自体で骨が脆弱になっていることを示 す端的な証拠であるからであろう。また、喫煙、 遺伝性など骨量以外のリスクファクターが 1 つあ れば、「-2.0SD未満」の例を骨折予防の薬物治療 の対象とすることを勧めている。

6. 日本における骨粗䇗症診療の今後の課題

今後、日本でも、骨折試験を済ませた薬物が使 用されるようになる。骨折試験の意味するところ は、「脆弱性骨折を防止し得る、又は、脆弱性を 改善し得る」ということであり、「骨量の維持増 加効果」とは、似ているが同じではない。脆弱性 骨折防止の観点から、1．脊椎骨折のある骨粗箖 症の骨量測定と治療をどうするか? 、2．骨折が 無く骨量のみで診断される骨粗鬆症の治療適応を どうするか？、3，骨量減少症の中にも脆弱性骨 折を生じる例があるが、これをとのように扱うか？ などが課題となろう。

今まで、骨粗彩症の治療適応は、骨量の維持之 増加効果を基本に考えられる傾向にあった。しか
し、少なくとも、「脆弱性骨折の予防効果」が明 らかになった薬物による治療の適応は、骨脆弱性 を中心に考える必要がある。日本人の骨粗彭症に よる脊椎骨折の発症率は欧米人より多いと推定さ れる。脊椎脆弱性改善を目指した薬物の治療適応 は、日本において特に重要なことと思われる。骨 量以外のリスクファクターの脆弱性骨折との関連 を明らかにすることが必要であろう。 